\title{
Friedrich Robert Helmert, founder of modern geodesy, on the occasion of the centenary of his death
}

\author{
Johannes Ihde ${ }^{1}$ and Andreas Reinhold ${ }^{2}$ \\ ${ }^{1}$ Helmholtz Centre Potsdam - German Research Centre for Geosciences (GFZ) Telegrafenberg, 14473 \\ Potsdam, Germany \\ ${ }^{2}$ Federal Agency for Cartography and Geodesy, Richard-Strauss-Allee 11, 60598 Frankfurt am Main, Germany \\ Correspondence to: Johannes Ihde (johannes.ihde@gfz-potsdam.de)
}

Received: 29 March 2017 - Accepted: 14 June 2017 - Published: 8 August 2017

\begin{abstract}
Friedrich Robert Helmert died in Potsdam in 1917 at the age of 74 after serving for over 30 years as director of the Royal Prussian Geodetic Institute and of the Central Bureau of the Internationale Erdmessung, the forerunner of today's International Association of Geodesy. He dedicated his life and his scientific career to the field of geodesy. His teachings on theoretical and physical geodesy were incorporated into university curricula around the world and hence into international endeavours to measure planet Earth. The purpose of this article is to illustrate the impact he has had on the development of modern geodesy and on the related sciences.
\end{abstract}

\section{Prologue}

The full professor of geodesy and director of the Potsdam Royal Prussian Geodetic Institute, with the official title of Geheimer Oberregierungsrath Prof. Dr. Dr.-Ing. e. h., Friedrich Robert Helmert died in Potsdam on 15 June 1917. Over the past 100 years, a great number of publications have paid impressive tribute to Helmert's life and work (e.g. Wolf, 1993; Buschmann, 1993c; Höpfner, 2013b). On writing this article, the authors were from the start aware of how challenging it would be to reveal a new perspective on Helmert's life of work in the service of the Earth sciences. We have therefore concentrated our efforts on relating his life and his achievements to the conditions and developments of his time and to answering the following question: what were the circumstances that allowed Helmert to be so productive and to generate teachings whose significance continues to resonate beyond geodesy and throughout the Earth sciences?

Helmert developed his concept of a modern, mathematicsand physics-based geodesy with his 1868 dissertation on efficient measurements entitled Studien über rationelle Vermessungen im Gebiet der höheren Geodäsie, his 1872 book on least squares called Die Ausgleichungsrechnung nach der Methode der kleinsten Quadrate - Mit Anwendungen auf die Geodäsie und die Theorie der Messinstrumente (Helmert, 1872a), and the two volumes of 1880 and 1884 since trans- lated into English as Mathematical and Physical Theories of Higher Geodesy. Helmert also lent his talents to the needs of industrialisation with his 1872 work on railroad surveying entitled Die Übergangscurven für Eisenbahn-Geleise mit Rechnungs-Beispielen und Tafeln für den praktischen Gebrauch (Helmert, 1872b). All of these publications also served as a leitmotif for his scientific, practical and technically oriented activities at the Royal Prussian Geodetic Institute from 1886 until his death in 1917 and, from 1900 on, as a member of the Royal Prussian Academy of Sciences. Helmert was the first member of the academy to bear the occupational title of "Geodesist".

His trailblazing scientific publications and organisational work have exerted a lasting impact on university education around the globe and left an enduring mark on the careers of generations of geodesists and geophysicists. Helmert's profound and systematic contributions to the natural sciences and technologies are without doubt one of the reasons that the International Union of Geodesy and Geophysics includes in its title the name of the scientific discipline that Helmert founded (Fig. 1).

Even though Helmert's scientific achievements lie over a century in the past, it is worth looking back to examine the historical background to the success of the Internationale Erdmessung (IE) (Torge, 2007). 


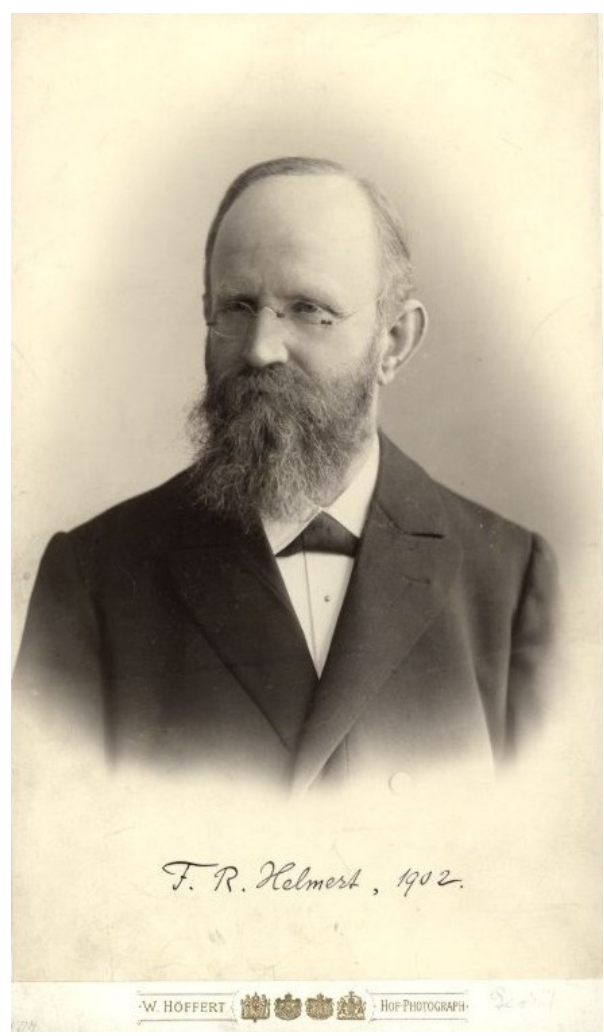

Figure 1. Friedrich Robert Helmert (Humboldt University Berlin, (CHumboldt-Universität zu Berlin, Universitätsbibliothek).

\section{Youth and education}

Friedrich Robert Helmert was born on 31 July 1843 in Freiberg, Saxony. He was the youngest of 17 children born to hospital foundation treasurer Johann Friedrich Helmert and his second wife Christiane Fredericke, née Linke. Many of his siblings died while still young. The family lived in the house at Nonnengasse 17, which belonged to his father. Helmert grew up in a middle-class environment. His family had in earlier years been connected to the mining sector that characterises the Freiberg region (Berroth, 1953).

$\mathrm{He}$ was a pupil of the Knabenbürgerschule in his home town from 1849 until 1857, when at age 13 he was able to transfer to the Annenrealschule in Dresden, where his (half) brother worked as assistant headmaster and botanist. From here, "after passing the graduation exam with good marks I transferred to the Polytechnic College of Dresden on Easter of 1859, skipping the first year, and immediately succumbed to my penchant for the engineering sciences" (Gast, 1921). Helmert graduated from the Annenrealschule with top marks and was rewarded with a copy of Eisenlohr's Physik, a physics coursebook by Wilhelm Eisenlohr. At the Royal Polytechnic College, the forerunner of today's Technical University of Dresden, Helmert quickly developed an inclination towards the field of geodesy, an inclination that was recognised and encouraged by his teacher, Prof. Christian August Nagel (1821-1903). While still a student, Helmert was able to take part in field work for the triangulation of the Erzgebirgisches Kohlenbassin ("Ore Mountains coal basin") and for the Saxon meridian arc measurement. The first project in particular clearly revealed the growing importance of geodesy for Saxony's nascent industrialisation, despite the fact that detailed surveys of the bituminous coal beds had been called off, as it was already apparent that these deposits were limited. In this project, Helmert was involved in levelling operations and in calculating elevations. During his 1860-1961 year at university, Helmert was enrolled in the "Lower Department, First Class, Section B for Road, Hydraulic, Bridge and Railway Engineering" (Hülsse, 1861).

Helmert's outstanding university performance was a key factor in Nagel's decision to take him on as a Gradmessungsassistent (arc measurement assistant) in the summer of 1863. In the previous year, the Kingdom of Saxony had joined the Mitteleuropäische Gradmessung (Central European Arc Measurement), for which Nagel, as Saxony's Gradmessungscommissar (arc measurement commissioner), in 1863 assumed responsibility for the work on the triangulation network. Supplemented by a second-order network of the Royal Saxon Triangulation, the central European network quickly grew to comprise 150 triangulation stations, each of which had to satisfy high standards of coordinate accuracy and demonstrate sustained stability. By helping to design the network, perform station reconnaissance, erect and secure the stone columns, and conduct surveys, Helmert had delved into a broad and interesting spectrum of activities: "In undertaking diverse investigations of the terrain using plane table and chain, in performing geometric and trigonometric surveying and geometric and trigonometric levelling, in learning the use of the theodolite and the universal instrument, and in carefully following the work of the Polytechnic College's engineering department, I have been given ample opportunity to familiarise myself with the practical side of both the 'lower' and 'higher' measurement arts, all with the obliging support of Professor Nagel. The processing of the observations offered the chance to practice drawing and drafting, but above all to acquire meticulous knowledge of the mathematics of geodesy." (Gast, 1921).

Helmert's extensive description of the procedures used for reconnoitring and erecting the stations alone took up 22 tightly written pages of his 1865 annual report, which was further supplemented by 26 separate reports (HStA Dresden 1). In his special report to the Royal Saxon Ministry of Finance, Nagel attested to the industriousness of his assistant: "In the year 1865, Assistant Helmert spent 179 days outside of and 147 days in Dresden, giving a total of 326 days, in the service of the arc measurement in Saxony. Moreover, he was, at Prussia's expense, 8 days in the Harz mountains to set observation pillars there for General Baeyer, and he worked 31 days on the triangulation of the Ore Mountains coal basin.... 
As regards his field activities, these consisted of ... special reconnaissance ..., in particular supervising pillar construction, supervising signal pyramid construction, employing and inspecting heliotropists and assisting during angle observations on Lausche mountain. Concerning these activities he has produced a special report, to which I take the liberty of referring. In Dresden he was occupied with the elaboration of various pillar projects, with the preparation of drawings and protocols for the executed pillars and with initiating the computation of angle observations." (HStA Dresden 2).

Even as a student, Helmert had worked according to the principle of close theory-practice integration that is inherent in the discipline of geodesy. He thus drew on the knowledge and experience gained as an assistant in the arc measurement project when drafting a scientific paper on the efficiency of geodetic measurements entitled Studien über rationelle Vermessungen der höheren Geodäsie, in which he investigated the inclusion of lower-order points in a national triangulation and which he later submitted and published as a doctoral thesis in Leipzig (Helmert, 1868). "With Professor Nagel's consent, I departed on Michaelmas day of 1866 to go for one year to Leipzig to further perfect my knowledge of mathematics, astronomy and other disciplines of general interest". This study visit was made possible by a travel scholarship granted to him by the academic staff of the Polytechnic College at the end of his studies (Gast, 1921). The courses he attended during the winter semester of 1866-1867 included "Practical National Economics, Higher Equations, Determinants, Stellar Astronomy, Elliptic Integrals, and the Epistemology of Locke, Leibniz, Hume and Kant". In the 1867 summer semester he heard lectures on "Kant's Theory and Criticism of Knowledge, Elliptic Integrals, Higher Algebra, Analytical Mechanics, Theory of Algebraic Integrals, Presentation and Criticism of Hegel's Philosophy, and Geographic Positioning with Practical Exercises in the Observatory and Meteorology" (UA Leipzig).

Under the directorship of Prof. Dr. Carl Christian Bruhns (1830-1881), the astronomical observatory at the University of Leipzig enjoyed an outstanding reputation both at home and abroad. Construction work on a new observatory was completed in 1861 and operations were moved from the Pleissenburg fortress to the Johannistal area on the city's outskirts. Bruhns, who also served as a Gradmessungscommissar (arc measurement commissioner) for the Kingdom of Saxony, was responsible for the astronomical work and for directing baseline measurements. His recommendation to the philosophy faculty to accept Helmert's dissertation included the following praise: "During his studies here, Mr. F. Helmert attended my lectures with exceptional diligence and used the instruments at the local observatory to make observations ... frequently to my great satisfaction, and then fully reduced these observations. The results obtained pay witness to his great zeal and sound understanding and reveal a particular talent for astronomical and related observations. ... Mr. Helmert's dissertation is a good and almost completely new work in that its subject has hardly been examined by anyone prior to him. It basically concerns the application of probability theory to solving geodetic problems." (UA Leipzig). Helmert was awarded his Ph.D. on 12 May 1868 after he had "with respect to the oral examination" wished that "this might preferably include physics, particularly the more deductive areas thereof, and further mathematics and mechanics as well as practical astronomy, with special consideration possibly given to its geodetic aspects". (UA Leipzig).

So again in Leipzig, Helmert's activities remained closely associated with arc measurement work, and it is not surprising that he returned to this field after completing his studies in late 1867, taking up computational assignments in January 1868 and erecting a pillar in the town of Hohburg near Wurzen, from 5 to 7 July of that year (Fig. 2).

From 22 July to 27 October 1868 he worked on assignment from Bruhns at the Pleissenburg fortress in Leipzig and at five other stations near the city. Here he conducted determinations of the astronomical latitude and the azimuth and performed angle measurements to determine the geodetic position of the stations. For this work he used a 10 in universal instrument by Pistor \& Martins. Back in 1864 the First General Conference of the Central European Arc Measurement held in Berlin had already decided to include further stations in the astronomical measurements used to investigate deflections of the vertical in the vicinity of observatories. Helmert's work served this objective. After the geodetic determinations for these stations were completed, Nagel was able to present the results, in Helmert's presence, at the Eighth General Conference of European Arc Measurement, which convened in Berlin in 1886 (Hirsch, 1887).

Those months of 1868 also saw Helmert assisting Nagel with his "discussion of exact standard weights of the Standard Calibration Commission" and working - in what was certainly a purely bread-earning position - as a mathematics instructor at Dr. Hölbe's private school in Dresden (Gast, 1921). The mutual attachment, appreciation and professional exchange between Nagel, the teacher and practitioner, and Helmert, the student and theoretician, endured for a lifetime.

\section{The origins of the Internationale Erdmessung}

Starting in 1859 many important decisions and initial steps were taken towards the conception of a new European arc measurement project. Geodetic arc measurements in the 18th century were done primarily to determine the size and shape of the Earth. The Struve meridian arc was the most expansive such project in Europe, comprising 258 main triangles and stretching over $2800 \mathrm{~km}$ from Hammerfest to the Black Sea. In 2005 it became the first scientific instrument to be placed on the UNESCO World Heritage List. It was the product of early cross-border collaboration over an area that today encompasses 10 nations (see also Torge, 2016). 


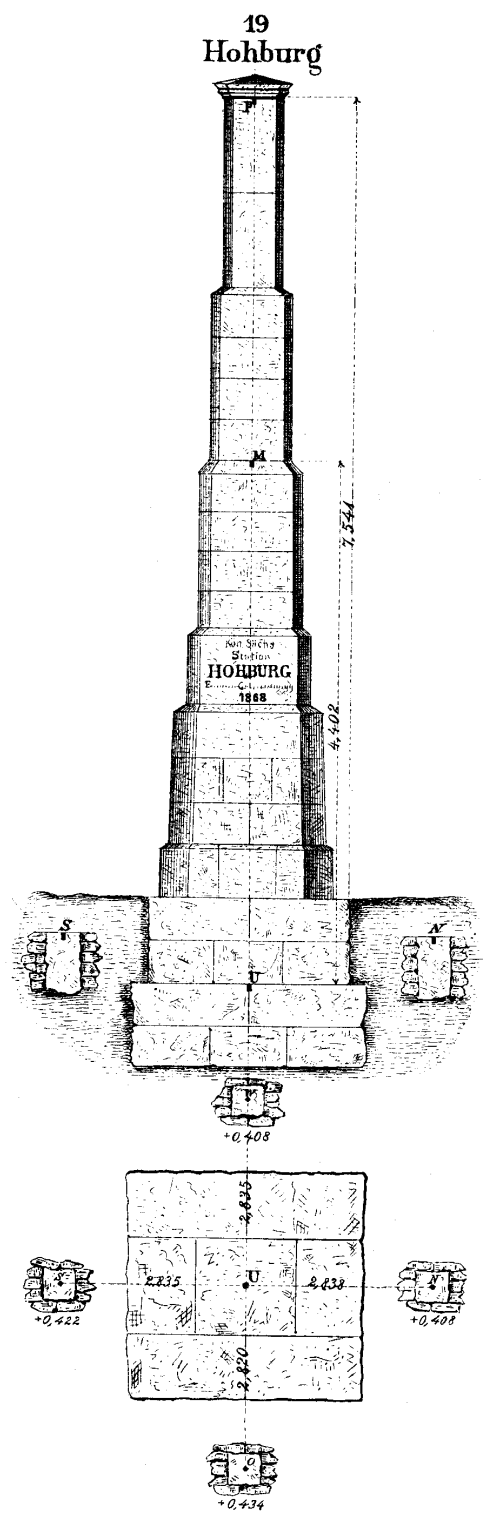

Figure 2. $7.5 \mathrm{~m}$ high Saxon geodetic pillar in Hohburg, built in 1868 under Helmert's supervision (Nagel, 1890).

General Johann Jacob Baeyer (1794-1885), as head of the Trigonometric Department of the Prussian General Staff, was involved in conceiving, executing and leading many geodetic surveying projects, including those carried out by Friedrich Wilhelm Bessel (1784-1846) in East Prussia. He repeatedly submitted proposals for improving the national survey. These, however, failed to gain the acknowledgement and appreciation he expected. In an 1868 memorandum, which would ultimately also serve to support the establishment of a geodetic institute, he complained about what had transpired 15 years previously: "The agitation against my bent for innovation seemed to have waxed rather than waned. ... General von Radowitz ... and A. von Humboldt were the only ones who took notice of my scientific endeavours" (Baeyer, 1868). Even the assessments submitted by Alexander von Humboldt (1769-1859) were not sufficient to advance Baeyer's plans. Following disputes with fellow members of the Prussian General Staff, Baeyer withdrew from this body in 1857 . The King, in appreciation of Baeyer's service and achievements, placed the general zur Disposition, or z. D. (at disposal) in 1858 , meaning that he was suspended from active duty while still receiving a full salary.

Given his experience in geodetic surveying and his good contacts with renowned scholars, Baeyer was inclined towards the natural sciences and mathematics, and he possessed, as most generals do, a pronounced talent for the organisation of projects. Both sides of his character were apparent in the proposals he made (Dick, 1994a, 1996).

In his 1861 memorandum arguing for the establishment of a central European arc measurement project and entitled Über die Größe und Figur der Erde ("On the Size and Figure of the Earth"), Baeyer posed two basic questions which still today lie at the heart of geodesy:

- Does the position of the Earth's axis, and hence the astronomical latitude, remain constant, or does it vary over time?

- Has the time it takes for the Earth to revolve around its axis always been the same, or has it changed? (Baeyer, 1861).

As a general, Baeyer placed great importance on organising work with military precision. It was in this spirit that he invited representatives of Saxony and Austria to Berlin in 1862 for a preparatory conference aimed at initiating a collaborative project and devising its organisational framework. The plan was to establish a large-area trigonometric network from Norway to Sicily and from London to Königsberg (Buschmann and Kautzleben, 1987).

Following an - at first unsuccessful - enquiry to the Saxon ministries, the Ministry of Finance ordered that Saxony should join the Central European Arc Measurement organisation. The Kingdom of Saxony joined the project on 28 May 1862. Three Gradmessungscommissare (arc measurement commissioners) were appointed: the professors Julius Weisbach (1806-1871) of the Royal Saxon Mining Academy at Freiberg, Bruhns from the University of Leipzig, and Nagel from the Royal Saxon Polytechnic College in Dresden. The bringing together of these three men would have a decisive influence on Helmert's career.

Baeyer, embittered by his initial failure to push his ideas through, fought obstinately for his project. As early as 1864, the First General Conference of delegates to Central European Arc Measurement was attended by representatives of 15 countries. The scientific directorship of the project was assumed by a "Permanent Commission", while organisational matters were handled by a the Central Bureau, which was established in 1866 and directed by Baeyer. The Central Euro- 
pean Arc Measurement group initiated the process of linking Earth system research with practical applications that could also be reliably organised across international boundaries.

Further countries joined the project at its second General Conference in 1867, leading the organisation to rechristen itself the Europäische Gradmessung ("European Arc Measurement"). Physical measurements were added to the programme, including levelling, gravity and water level measurements. Wilhelm Foerster (1832-1921), since 1865 director of the Berlin Observatory, had from the beginning supported Baeyer's plan for organising the arc measurements and creating an Institut für höhere Meßkunde ("Institute For Advanced Metrology”). In 1867 Baeyer and Foerster jointly drafted a memorandum on the issue entitled Promemoria betreffend die Organisation eines Instituts für höhere Meßkunde that would eventually lead to the founding in 1870 of the Royal Prussian Geodetic Institute (RPGI) in Berlin.

In a further memorandum written in 1868, Baeyer once again made the case for the establishment of a scientific central authority for geodesy in order, among other things, to safeguard the work of the Central Bureau. This memorandum elicited intense disputes between Baeyer and noted academics, not to mention government ministries, concerning the direction of the scientific institute Baeyer was proposing. Following subjective and very personal attacks from Baeyer, Foerster in 1868 quit the Central Bureau of the recently constituted European Arc Measurement organisation and did not resume his work in the field of geodesy until after Baeyer's death. Baeyer thus lost a key supporter to his cause. The RPGI Berlin took up residence in tenement houses. Baeyer became the first director of the Geodetic Institute Berlin (GIB) and remained both in this post and in the post of director of the Central Bureau of European Arc Measurement until his death (Buschmann, 1994a).

During Baeyer's time as director, the Royal Prussian Geodetic Institute experienced no major changes. Although the Prussian Academy of Sciences (PAdW) had after 1870 already planned to establish observatories on the Telegraphenberg (Telegraph Hill) near Potsdam, Baeyer opposed the idea because he thought the distance between the institute's activities and the Berlin Academy would be too great and the institute would become scientifically isolated.

On 1 July 1874 a proposal by Foerster and others was realised with the founding of the Astrophysical Observatory Potsdam (AOP). It was the first of its kind in the world and had a special concentration on stellar physics. Initially it was housed in the former military orphanage in Potsdam's Lindenstraße. The main building on the Telegraphenberg was completed in the autumn of 1879. The AOP was the first institute to take up residence in what would evolve into an important centre for the sciences on Potsdam's Telegraphenberg.

\section{Helmert's productive period in Hamburg and Aachen}

In the months after receiving his doctorate in Leipzig, Helmert had to make up his mind as to the direction he wanted his career as a geodesist to take. He had developed a preference for work in the field of "higher" (i.e. global-scale) geodesy, and had as early as 8 June 1868 applied to Baeyer for a post in the planned Geodetic Institute. In his letter he wrote that he intended "to become an instructor of geodesy or to take an appropriate position of applied practice". It was for this same reason that Helmert rejected an offer from the observatory in Leiden. As the RPGI would not be founded until 1870, Baeyer offered Helmert a temporary position in the Central Bureau of European Arc Measurement. This job, however, was so poorly paid that Helmert could not accept the offer (Buschmann, 1993a).

In early 1869 took up his post as an observer at the Hamburg Observatory. "I left my position at the Saxon Arc Measurement due to the good facilities at the observatory and in view of the fact that three superb craftsmen reside in Hamburg: the mechanical engineer Johannes Repsold, the optical engineer Hugo Schröder and the chronometer maker Knoblich.” (Gast, 1921). Headed by Dr. George Rümker (1832-1900), the Hamburg Observatory was at this time still located at the Millerntor gate (it was moved to Bergedorf in 1909 and officially opened there in 1912). The observatory's primary instrument, installed in 1867, was an equatorial telescope built by A. Repsold \& Söhne and used by the various - and frequently alternating - observers to continuously observe all of the comets visible from this site, to view interesting small planets, to conduct a large number of position determinations of star clusters and nebulae, to perform binary star measurements, and, as Helmert did, to measure the star cluster in the Sobieski's Shield. Helmert reported on this work in 1874 in the publications of the Hamburg Observatory (Helmert, 1874). The observatory's primary activity, however, was the determination of the exact time (Schorr, 1901). Helmert's observation books contain numerous notes on his work as an observer in Hamburg. Besides those concerning regular clock comparisons, e.g. "Difference to standard clock in sec. unknown, min. correct (clock stopped). The clock no longer struck at the last wire, so listened for other clock that strikes about 0.15 earlier"; we also find notes on his work with the equatorial telescope and the transit instrument: "It's apparent that temperature changes have an effect, and the heat in the dome is atrocious." The following was added later in ink: "Because the telescope tube cover had been put on." And elsewhere is written "I notice that the adjusting screw on the telescope's setting circle is bent, which certainly wasn't the case before. And no one wants to admit to running into it. We can only wait and see whether the errors will have changed". There are also interesting marginal notes, such as this one about Jupiter: "Jupiter shows very marked stripes. Quite intense, with very sharp borders and grey, then a con- 


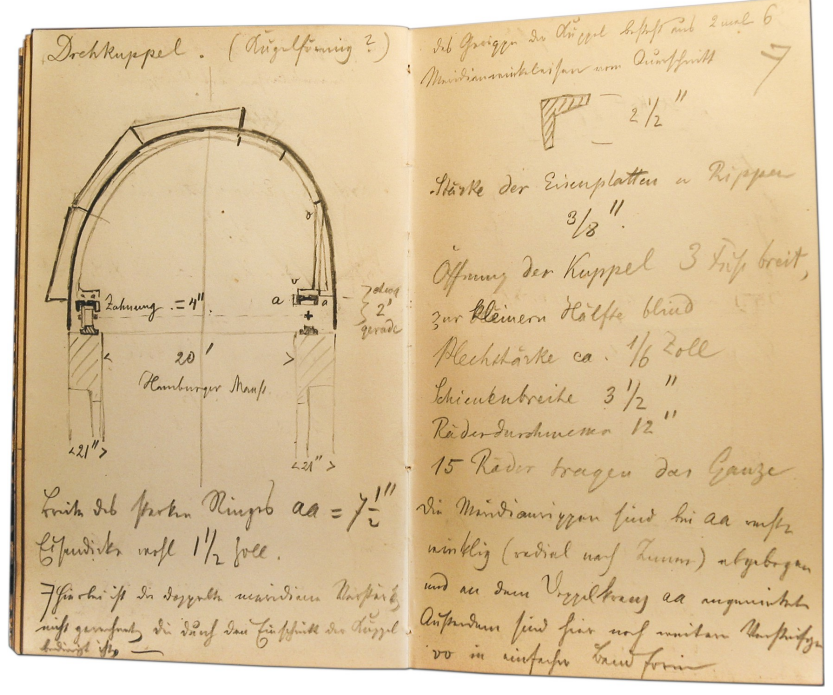

Figure 3. Helmert's observation book, Hamburg Observatory at Millerntor (Stw/Observatory Hamburg: Sternwarte HamburgBergedorf, Archiv Bibliothek, Beobachtungsbücher F. R. Helmert).

siderably large brick red stripe, $\ldots$ and something with a reddish shimmer at the bottom". Notes on aurora sightings can also be found (Stw. Hamburg).

But Helmert's thoughts also turned to the development of improved measurement technologies, as can be seen in entries concerning the design of a rotating dome for the observatory (Fig. 3). Helmert remained in Hamburg until August 1870, leaving to take on a full teaching post in Aachen that had been offered to him in January.

From the founding of the Royal Rhine-Westphalia Polytechnic College in Aachen in the 1870-1871 winter semester until the end of 1885, Helmert served as an "Ordinarius" for Practical Geometry and Geodesy (later: Practical Geometry and Geographic Positioning). The CV with which he had applied for this post provides a source for some of the information quoted here (Gast, 1921). In this position he was simultaneously director of both the geodetic collection and the map collection. On 21 December 1872 he was appointed professor and in 1882-1883 he was elected to the college senate. In 1883-1884 he served as the head of Department II for Construction Engineering and again as a college senator (RWTH, 2003). He divided his lectures into three blocks: Practical Geometry I included "lower" (regional-scale) geodesy, II covered curve fitting and spherical astronomy, while III investigated routing, geodetic surveying and geodesy. He would also hold special lectures on theoretical astronomy, arithmetic and algebra, particularly during his first years at the college (Gast, 1921).

But Helmert would once again return to the Saxon Arc Measurement project. In 1872 - while already working in Aachen - he served in August and September as "first observer for wedge readings, levelling readings and plumb line

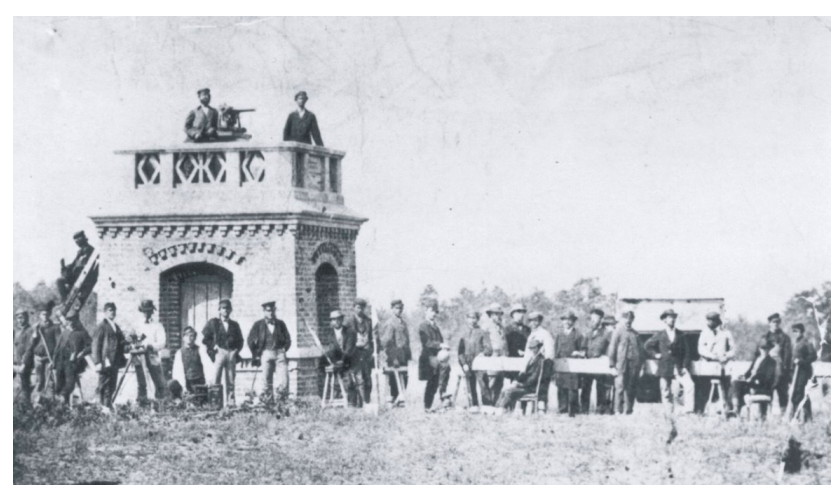

Figure 4. Baseline measurement in Großenhain in 1872, western end point at Raschütz, Nagel (left) and Helmert on the observation building (unknown source).

angle measurements" (Nagel, 1882), in other words as first observer for the Saxon baseline measurement at Großenhain (Fig. 4). Nagel worked as second observer on this survey, while Bruhns acted as the organisational director. The measurement of the Saxon baseline had finally been completed in 1865 and building work on the end points had begun. The war of 1866 interrupted this work and in 1867 - when Helmert was still in Saxony - the plans for the railway line between Großenhain and Cottbus were completed, plans that made it necessary to move the baseline $300 \mathrm{~m}$ to the north. Construction work at the baseline's end points then took until early 1872 to complete.

In October of 1872 Helmert received a letter with an invitation to take part in an "expedition to observe the transit of Venus across the sun in 1874" after he had previously expressed a certain interest in the event to Bruhns, a member of the preparations committee. But "following careful consideration of all circumstances" he regretfully and apologetically declined. Helmert expressed his gratitude for the trust placed in him but stressed that he could not turn his students' education over to the care of another for such a long period, particularly since the required personnel were not available (ABBAW 1, 1872-1874). He likewise declined calls to go to Córdoba in Argentina in 1873 or to succeed Jordan in Karlsruhe in 1881 .

In 1877, Helmert became a member of the Berlin Geodetic Institute's scientific advisory council, which had been installed by the Prussian Academy of Sciences. This move brought Helmert back into closer contact with the concerns of European Arc Measurement (RWTH, 2003).

\section{Helmert's contribution to establishing geodesy as a scientific discipline}

Until the mid-19th century, geodetic questions were investigated by mathematicians, astronomers and physicists. The discipline of geodesy as we define it today did not exist. 
Even Baeyer's work with European Arc Measurement did not give him a comprehensive picture of how geodesy should be structured and aligned in the future.

Besides Helmert, another of the young scientists involved in European Arc Measurement, Ernst Heinrich Bruns (18481919), would also achieve a position of prominence. As a mathematician, physicist and astronomer, he had access to the theories of geodesy developed in the context of international projects. After working as a calculator at the Pulkovo Observatory in 1872-1873 and then as an observer at the observatory in Dorpat (now Tartu), Bruns was in 1876 appointed as a non-tenured professor of mathematics in Berlin. His activities at these two renowned centres of astronomy certainly helped shape his geodetic outlook. Pulkovo and Tartu were scientific centres for the work on the Struve meridian arc, the forerunner project to the Central European Arc Measurement.

In September of 1877 Bruns had already completed one of his most important publications Die Figur der Erde - Ein Beitrag zur Europäischen Gradmessung ("The Figure of the Earth - A Contribution to the European Arc Measurement"). Here Bruns writes that "the task of geodesy is not to determine the mathematical figure of the Earth, but rather to determine the force function W" (Bruns, 1878), by which Bruns meant the determination of all level surfaces, i.e. the entire gravity field of the Earth. His contribution is a milestone in the development of theoretical and physical geodesy and differs fundamentally from Baeyer's treatises, which essentially followed a mathematical approach, as expressed in his 1862 work Das Messen auf der Sphäroidischen Erdoberfäche ("Measuring on the Spheroidal Surface of the Earth").

Simultaneously with Bruns, Helmert likewise occupied himself with the questions of theoretical geodesy. "Geodesy is the science of measuring and representing the Earth's surface." This was the first sentence in his Die Mathematischen Theorien, which formed Part I of his primary work, Die Mathematischen und Physikalischen Theorien der Höheren Geodäsie ("Mathematical and Physical Theories of Higher Geodesy"). Following the appearance of Part I in 1880, Helmert published Part II, Die Physikalischen Theorien, in 1884. Helmert was of course familiar with the work of Bruns. In the foreword he writes: "The completion and publication [of Part II, ed.] was delayed due to the now acknowledged need to precede it with a description of the mathematical theories, and I became even less rushed when in $1878 \mathrm{H}$. Bruns, in his treatise on the figure of the Earth, delivered an extraordinarily brilliant overview of the topic". (Helmert, 1884). Helmert was now delving deep into the theoretical realm, laying the groundwork for the proper execution of gravity and elevation measurements.

The definitions provided by Helmert and Bruns concerning the purpose of geodesy do not contradict one another. Helmert generalises and expands on the mission of geodesy as seen by Bruns. Bruns's definition is still important today to the extent that it explicitly states that the determination of the Earth's gravity field is the task of geodesy. On the fundamental issues, Helmert agreed with Bruns without reservation. Helmert also backed the nomination, made by Hermann Struve (1854-1920), of Heinrich Bruns to fill the professorship position at Leipzig University's observatory that had been left vacant by the premature death of Christian Bruhns in 1881. Bruns was able to prevail over renowned international candidates and was awarded the position.

At the RPGI the determination of the gravity field was a central part of Helmert's work for three decades.

\section{At the Royal Prussian Geodetic Institute (RPGI)}

With the publication of his two-volume work on the theories of geodesy, and with his participation in many scientific projects, the 40-year-old Helmert had already earned a top ranking among his colleagues in the geoscientific community. Moreover, Helmert had for years maintained good contacts with the operational heads of European Arc Measurement through his correspondence with General Carlos Ibañez de Ibero (1825-1891), since 1874 president of the Permanent Commission, and with Adolphe Hirsch (1830-1901), secretary along with Bruhns since 1866 and permanent secretary from 1886 to 1900 . Helmert therefore became the sole and unrivalled candidate for the post of director of the Royal Prussian Geodetic Institute following Baeyer's death. He took up this position, initially in a provisional capacity, on 1 January 1886. The scientific orientation of the Prussian Academy of Sciences towards mathematics and physics exerted a lasting influence on the evolution of geodesy and geophysics.

Through his many years of service on the Scientific Advisory Council, Helmert was quite knowledgeable, and in some cases critical, of how the RPGI had been structured and operated under Baeyer's leadership. Baeyer's death on 10 September 1885 also called the existing organisational structure of European Arc Measurement into question. In 1886 both institutions began to search for solutions aimed at ensuring their continued existence under improved scientific and economic conditions. Although he remained in Aachen until early May 1886, Helmert helped to define the substance of the necessary reforms. Also of great importance was the return of Foerster to active geodetic work after a nearly 20-year hiatus.

As early as 15 March 1886, a conference was held in Berlin by the "Commission for the Negotiations on the Reorganisation of the Geodetic Institute". Besides representatives from the involved ministries, attendees included Colonel Oskar Schreiber (1829-1905) for the Ministry of War "as well as the established experts" Professor Dr. Arthur von Auwers (1828-1915), Foerster, Helmert and Professor Dr. Karl Maximilian von Bauernfeind (1818-1894), director of the Technical University of Munich. Enclosed with the invitation was a discussion paper entitled Entwurf der Grundzüge 
für die Organisation des geodätischen Instituts ("Draft Outline for the Organisation of the Geodetic Institute”). It contained the primary proposals concerning the preservation and scientific orientation of the Royal Prussian Geodetic Institute (ABBAW 2, 1884-1888):

1. The directorship of the RPGI will be tied to a professorship at the University of Berlin. This will accentuate the academic work of the institute and facilitate international relations.

2. The Scientific Advisory Council will be abolished since the institute will be led by a scholar and be an institution of the university.

3. "The rivalry between the Geodetic Institute and the National Survey will end." (ABBAW 2, 1884-1888). The RPGI will lay the scientific groundwork for trigonometric and levelling activities, which will then be executed and analysed by the National Survey. Requests of the RPGI concerning measurement guidelines and accuracy should be taken into consideration.

4. The RPGI may carry out its own measurements if the National Survey does not have the required capabilities. The publication of results is to be coordinated in advance.

5. The RPGI is to conduct computational and experimental studies on geodetic work "in order to be able to provide appropriate expert advice, on request, to the various departments of the state administration". (ABBAW 2, 1884-1888).

6. Suitable facilities are to be provided for the institute, preferably in a new building on the Telegraphenberg near Potsdam.

7. The RPGI will continue its work for international geodesy and continue to run the Central Bureau.

On 26 May 1886, a few days following Helmert's move to Berlin, the RPGI held "Negotiations of the Plenary Assembly of the Scientific Advisory Council" in Berlin. It was attended by Auwers, Helmert, Hermann von Helmholtz (1821-1894), Leopold Kronecker (1823-1891) and Werner von Siemens (1816-1892), as well as by the section chiefs of the institute. In addition to the ordinary agenda items (A), which concerned the work of the previous year (1885) and the general working plan for 1886 , there were three extraordinary items (B), of which the item B3 in particular concerned the changes under discussion to the organisational structure of the RPGI and the Internationale Erdmessung:

B1 Overview of the work of the Geodetic Institute under Lieutenant General z. D. Dr. Baeyer.

B2 General working plan for the next 10 years.
B3 Reports on the negotiations regarding the reorganisation of the institute.

Helmert came to Berlin with concrete ideas about how scientific work at the institute should proceed and, based on an analysis of its previous work, attempted to quickly implement these ideas. While the annual accounts and proposals (A) were discussed and approved in typical fashion, "a vibrant debate arose over items B2 and B3, which led the advisory council to declare the following: The advisory council refuses to officially comment on item B3 because the respective negotiations were conducted without the involvement of the academy or the advisory council and the outcomes thereof have not yet been brought to the attention of the Academy". Since the new organisational structure also impacted on the long-term working plan - including the longitude, latitude and azimuth measurements that would in future be done by the National Survey - three members of the advisory council were opposed to assessing the plan. Item B3 was not published in the minutes of the negotiations (Helmert, 1886).

Helmert had only had a few weeks to draft these landmark documents and to discuss them with decision makers. In this case, he apparently did not have enough time to convince everyone. The integration of the institute into the bureaucracy of the state government obviously required a significantly greater degree of planning and collaboration than he was used to from his time in Aachen. In the end, however, the new structure finally prevailed with the dedication of the new Geodetic Institute in Potsdam.

The second important question concerned the future of international cooperation projects. Since the mid-1870s, interest in European Arc Measurement had been expressed by institutions from outside of Europe as well. The US Coast and Geodetic Survey, for example, had been sending observers to the General Conferences since 1877.

Based on the discussions pertaining to the orientation of the Geodetic Institute and the development of geodesy, Foerster sent a letter from Neuchatel on 19 April 1886 in which he - with the backing of Hirsch and apparently Ibañez as well - laid out his ideas on how to strengthen the organisational structure of international geodesy: "During the past few months in Berlin we have not been idle but rather have first of all secured the future national status of the Geodetic Institute, of which Prof. Helmert shall assume the directorship". According to Foerster, the Central Bureau should be left undiminished in the RPGI, but the Permanent Commission should have more influence over its work and assume the function of the advisory council with respect to the bureau's international operations. The Permanent Commission would be funded through financial contributions of the member states, with this money used to pay a permanent secretary and to support scientific arc measurement work approved by the Permanent Commission. Such international funding would serve to strengthen the member states' bonds to the 
organisation's work and to deepen their involvement in defining scientific objectives (ABBAW 3, 1884-1888).

The changes to the organisational structure of the geodetic association were also approved, initially for 10 years, at the Eighth General Conference in late October 1886. The "agreement of 1886 concerning the organisation of international geodesy" adopted by the conference incorporated the fundamental reforms cited above from Foerster's letter. The conference elected General Ibañez as president of the Permanent Commission. Helmert became a member of the Central Bureau as well as its director (Hirsch, 1887). Helmert's international reputation also lay behind the decision to retain the Central Bureau of the organisation - which was that same year rechristened the Internationale Erdmessung (L'Association Geodesique Internationale) at the Royal Prussian Geodetic Institute. Even letters dated prior to 1886 often referred to the Internationale Erdmessung instead of the Europäische Gradmessung. The international orientation of the organisation was confirmed in 1888 when Chile, Mexico and Japan joined its ranks. In 1889, 25 nations belonged to the IE (Völter, 1963).

The year 1892 saw the completion of construction work on the Geodetic Institute's main building on the Telegraphenberg, allowing the institute to relocate from Berlin to Potsdam. This was followed by the building of the Geodetic Astronomical Observatory for latitude and time determinations and of the tower used for conducting angle measurements. The latitude and time determinations performed here earned the Geodetic Institute great prominence. In 1899 Helmert first reported on measurements conducted on the tower (Helmert, 1899), but it seems that this work did not attract a comparable level of attention from the work programmes of the institute.

The laboratories incorporated state-of-the-art construction, design and technology to ensure that they would satisfy the needs of scientists well into the future. The pendulum room in the basement of the main building was temperaturestabilised and outfitted with special pillars for use in the planned reversible pendulum measurements.

The working conditions that greeted Helmert on the Telegraphenberg were outstanding. He moved into an apartment provided by the RGIP in the institute's main house; the residence originally planned for the director of the Geodetic Institute had not been realised. But what was important to him was undoubtedly the atmosphere emanating from the work of great contemporary scientists and the proximity of institutes with a strong focus on mathematics and physics. Today we might say that this environment provided an ideal framework for interdisciplinary collaboration. Although the Physikalisch-Technische Reichsanstalt (PTR; Imperial Physical Technical Institute) was established in Berlin in 1887, this metrological and natural science research centre, under its first president, Hermann von Helmholtz, certainly fostered the physics orientation of the scientific work taking place in Potsdam - and vice versa.

As the first major German research institute concerned with the units of measure for length and time, the PTR was of fundamental importance for the field of geodesy. This in essence remains unchanged to this day, with the role of the PTR now performed by its successor organisation, the PTB (Physikalisch-Technische Bundesanstalt). It is furthermore fitting that the Geodetic Institute, in the form of the Department of Geodesy of the German Research Centre for Geosciences, is located at the Helmholtz Centre in Potsdam.

Helmert also worked on harmonising units of length, an endeavour he pursued with exactitude. The German Empire adopted the metric system in 1872. This meant that all existing measurements had to be converted from the old units. In 1890 he wrote to the head of the Prussian Survey, Major General Schreiber. A copy of this letter, written in Helmert's own hand, has survived:

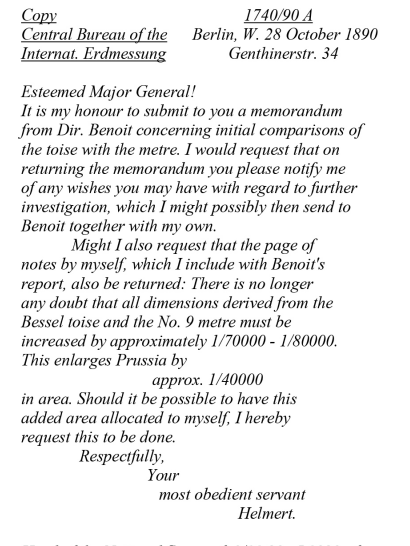
Head of the National Survev. f. 3/11.90-1.1980 - for your

His appointment as a regular member of the Prussian bureau of weights and measures was a logical development in the evolution of geodesy towards an exact science (Peschel, 1967). Still today, the close links between metrology and geodesy work to ensure precise and uniform geodetic measurements and calculations around the world.

In contrast to Baeyer, Helmert maintained good contacts to the Prussian Survey and to the academy leadership, and he must also have had a good sense of humour, as demonstrated in this letter.

In his memorandum Über die Größe und Figur der Erde ("On the Size and Shape of the Earth"), Baeyer had in 1861 already formulated the question as to whether the Earth's rotational axis moves over time (Baeyer, 1861). Evidence to this effect was provided by the astronomical observations done as part of European Arc Measurement. The monitoring of polar motion by means of simultaneous latitude observations was first discussed at the Seventh General Conference held in Rome in 1883. In a proposal submitted to the Permanent Commission in 1888, Foerster suggested systematically investigating latitude variation, the existence of which had been demonstrated by Karl Friedrich Küstner (18561936) while working as an observer at the Berlin Observa- 
tory. Helmert, as director of the Central Bureau, pushed for the establishment of a permanent international institution to monitor polar motion through latitude observations. Helmert reported on the results of the latitude measurements at the general conferences and at the annual conferences of the Permanent Commission.

In 1895 the 11th General Conference in Berlin renewed the contractual base of the Internationale Erdmessung. Its annual budget was increased to DEM 60000 (Deutsche Marks). A new Special Commission, to be directed by Carl Theodor Albrecht (1843-1915), was appointed to develop a concept for an international latitude service. In 1898, at the 12th General Conference in Stuttgart, Helmert and Albrecht submitted proposals for the latitude service. These were modified but ultimately adopted by the delegates (Helmert, 1913).

The International Latitude Service (ILS) officially launched its activities in 1899. This was an historic moment for the Earth sciences. The ILS, with five observatories on the 39th parallel, was the first permanent worldwide geodetic service. Albrecht headed the Central Bureau of ILS at the RPGI to prepare observation programmes and perform data reductions (Helmert and Albrecht, 1898b). The observations were initially done using the Horrebow-Talcott Method. From 1922 to 1935 the Central Bureau of the ILS was located at the International Latitude station at Mizusawa, Japan. This would evolve first into the International Polar Motion Service (IPMS) and in 1988 into the International Earth Rotation Service (IERS), which is today known as the International Earth Rotation and Reference Systems Service. The IERS is a joint service of the IAG, IUGG and the International Astronomical Union (IAU). In the year 2000, the Central Bureau was moved to the German Federal Agency for Cartography and Geodesy (BKG).

As director of the Geodetic Institute and in recognition of his scientific achievements (Fischer and Helmert, 1895; Galle, 1898), Helmert became a candidate to join the Prussian Academy of Sciences. In the minutes, signed by Auwers, of the meeting of the academy's Physics-Mathematics Class held on 11 February 1892, item 7 includes the following entry: "Finally, the elections of full members, as was announced in the previous session, took place" (Hermann Karl Vogel (1841-1907), Wilhelm Dames (1843-1898) and Helmert). All three candidates were elected by the class. Helmert, who was nominated on 21 January 1892 by Auwers with the backing of Hermann von Helmholtz, Johann Friedrich Wilhelm von Bezold (1837-1907) and August Kundt (1839-1894), received 12 white balls and 7 black balls at the election. The class then submitted its recommendation to the plenary session of the academy to accept all three professors as full members (ABBAW 4).

At the election held during the plenary session of the academy on 3 March 1892, Helmert failed to secure enough votes.

On 9 April 1896 Helmert submitted his report on the Ergebnisse der Messungen der Intensität der Schwerkraft

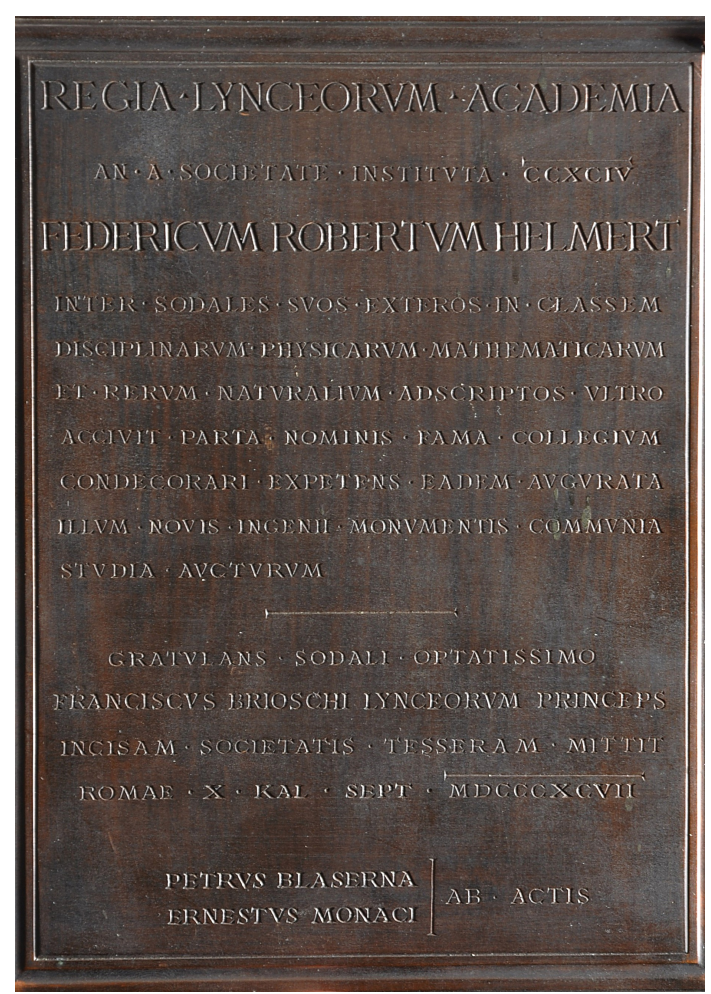

Figure 5. Commemorative plaque: "The Royal Academy of Sciences, in the 294th year after its founding, has accepted Friedrich Robert Helmert as a corresponding member of the PhysicsMathematics-Natural Sciences Class in acknowledgement of the renown he has gained through his endeavours to embellish this body and in the expectation that he will enrich common research efforts through new demonstrations of his talents. It is with cordial congratulations to our warmly welcomed colleague that the director of the academy, Francesco Brioschi, presents this inscribed plaque. Rome, 23 August 1897".

auf der Linie Colberg-Schneekoppe ("Results of Gravity Intensity Measurements on the Colberg-Schneekoppe Line"), which was handed to the meeting of the PhysicsMathematics Class by Prof. Dames (Akademie-Vorträge, 1993).

In 1897 Friedrich Robert Helmert was accepted as a corresponding member of the Physics-Mathematics-Natural Sciences Class of the Royal Academy of Sciences in Rome (Fig. 5).

On 16 November 1899, Hermann Karl Vogel re-nominated Helmert for full membership. This nomination was co-signed by professors Friedrich Kohlrausch (1840-1910), von Bezold, Ferdinand von Richthofen (1833-1905) and Lazarus Immanuel Fuchs (1833-1902) and confirmed by the meeting of the Physics-Mathematics Class on 30 November 1899, with 19 white balls to 1 black ball. At the plenary session held on 7 December 1899, Helmert received white balls from all 30 electors and the approval to join the academy of Sciences as a full member. Emperor William II issued his confir- 


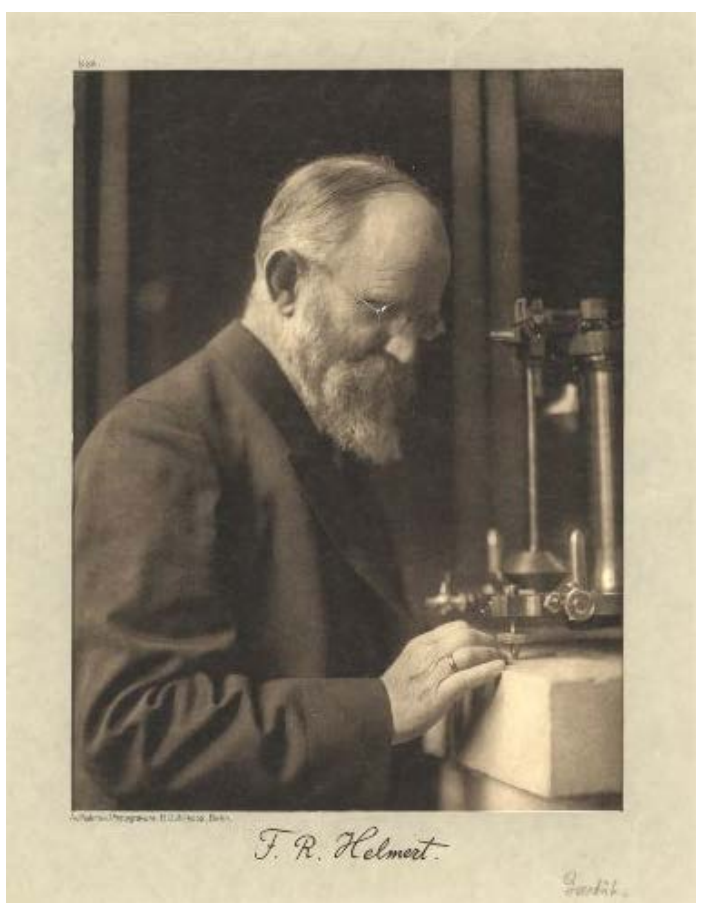

Figure 6. Friedrich Robert Helmert with a relative pendulum (Humboldt University Berlin, CHumboldt-Universität zu Berlin, Universitätsbibliothek).

mation on 31 January 1900, with notification sent to Helmert on 15 February. His response letter of 18 February 1900 included these words: "There will certainly be opportunity later to thank the Academy for selecting me; I first hope to make it to the general meeting next Thursday" (ABBAW 5).

In 1898 Helmert published his Beiträge zur Theorie des Reversionspendels ("Notes on the Theory of the Reversible Pendulum") (Helmert, 1898a). That same year, Kühnen and Furtwängler began their pendulum measurements. Following the reduction of the observations, an adjustment was performed using an approach by Helmert. The results were published in 1906 (Kühnen und Furtwängler, 1906; Höpfner, 2012). The calculated gravity value, $g=(981274 \pm 3) \mathrm{mGal}$, referred to the absolute pillar S0 at an elevation of $87.00 \mathrm{~m}$ $\left(1 \mathrm{mGal}=10^{-5} \mathrm{~m} \mathrm{~s}^{-2}\right)$. Taking up Helmert's recommendation, the 1909 conference of the Internationale Erdmessung in Cambridge, England, adopted the Potsdam Gravity System based on the absolute gravity value determined by Kühnen and Furtwängler. It was the first international gravity reference system (Fig. 6). Although Helmert had tasked his staff to perform the actual measurements, he can still rightfully be called the "father" of the Potsdam Gravity System (Elstner et al., 1997).

Later remeasurements conducted in 1968-1969 by the Geodetic Institute at the Central Institute for Physics of the Earth (ZIPE) yielded a value $14 \mathrm{mGal}$ lower: $(981,260.1 \pm$ 0.3) (Schüler et al., 1971). In 1971 a resolution of the 15th
General Assembly of the International Union of Geodesy and Geophysics (IUGG) replaced the Potsdam Gravity System with the International Gravity Standardization Net (IGSN 71 ), a move that corrected millions of gravity anomalies. The complete story is available in Höpfner (2012).

Each year Helmert presented oral reports on his work to the academy and also read the results of scientific activities that he had initiated. Most of his talks concerned the measurement and reduction of gravity, the modelling of the geoid, density distributions and changes in mass. A second topic set pertained to the dimensions of the Earth. On 12 January 1911, for example, Helmert presented his work Über die Genauigkeit der Dimensionen des HAYFORDschen Erdellipsoids ("On the Accuracy of the Dimensions of the HAYFORD Earth Ellipsoid"). An excellent documentation, with commentary, of the talks that Helmert presented to the academy is available in a modern edition (AkademieVorträge, 1993; Harnisch and Harnisch, 1993).

Helmert nominated or co-nominated George Howard Darwin (1845-1912) in 1908, Lorand Eötvös (1848-1919) in 1909 and Emil Wiechert (1861-1928) in 1911 as corresponding members of the Prussian Academy of Sciences, as well as Karl Schwarzschild (1873-1916) as a full member in 1912.

At the Geodetic Institute Helmert was able to extensively apply his ideas and theories in various projects. When we consider the great number of scientific problems, projects and publications he pursued, the correspondence and the work instructions he wrote (at the time all by hand), the wide range of administrative tasks he performed and, not least, his duties at the Central Bureau, we can only imagine how intensely he must have worked. Helmert was the sole author of over 100 publications. As director of the Geodetic Institute and the Central Bureau of the Internationale Erdmessung, he bore responsibility for nearly 100 reports (Höpfner, 2013a).

This unceasing hard work eventually took its toll on Helmert. He held his last talk to the academy on 21 October 1915, a presentation on Neue Formeln für den Verlauf der Schwerkraft im Meeresniveau beim Festlande ("New Formulae for Charting Gravity at Sea Level on Land") (Akademie-Vorträge, 1993). On the very same day, he wrote this petition to the academy (ABBAW 6): Potsdam, 21 Oct. 1915.
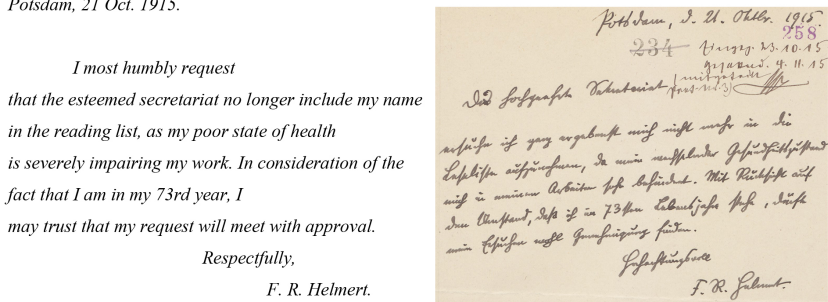

In accordance with the statutes of the Geodetic Institute of 5 January 1887, Helmert sent his last annual report on the activities of the Geodetic Institute to the Ministry for Spiritual and Educational Affairs on 25 May 1916. In his dealings 
with the ministry, Helmert demonstrated dependability and expertise, traits that were highly esteemed there.

Following a stroke in August of 1916, Helmert died on 15 June 1917 in Potsdam. Notice of his decease was transmitted to the academy by telegram:

the director of the geodetic institute professor helmert passed away this morning. funeral service monday 3 o'clock in the geodetic institute in potsdam $=$ professor krueger $(\mathrm{ABBAW} 7)$.

\section{The decline of the Geodetic Institute}

The search for a successor to Helmert as director of the Geodetic Institute proved to be as difficult as filling the directorship post at the Astrophysical Observatory left vacant by the death of Karl Schwarzschild. Prior to his own death in 1916, Helmert was a member of the nomination commission for this post together with Max Planck (1858-1947) and Albert Einstein (1879-1955). Soon afterwards, in 1917, a replacement also had to be found to head the Geodetic Institute.

Based on a ministerial decree of 17 July 1917, an eightmember commission was established that same month to "refill the position of Director of the Geodetic Institute left vacant by the death of Helmert" (ABBAW 8). The chair of the commission was assumed by the academy's permanent secretary, Max Planck. Einstein would be elected later to the commission. The debate on who should replace Helmert was contentious and would drag on for years. The commission was well aware of the risk that Helmert's principal works in support of European and international geodesy might not be brought to fruition. There was disagreement as to the significance of Helmert's various fields of activity. The members did agree, however, that his vertical deflection and geoid determinations were of central importance. No mention was made of the Potsdam Gravity System, possibly because they did not directly connect it with Helmert.

One fundamental question was whether a geodesist or geophysicist should be nominated for the office, or whether it was more important to appoint a scientist of renown without particular regard to his discipline.

Ultimately the opinion prevailed that "in the current situation primary emphasis must be placed on appointing an outstanding scholar" (ABBAW 14, p. 61).

In retrospect it seems clear that no matter who was appointed, the personnel and financial situation would not allow for an immediate return to the complex array of activities carried out under Helmert.

After the candidates Krüger (Potsdam), Hecker (Strasbourg), Schweydar (Potsdam), Kohlschütter (Berlin) and Schumann (Vienna) had been rejected as too narrowly specialised and too lacking in scientific authority to fill the vacant post, the name of geophysicist Emil Wiechert of Göttingen was put forward in November 1917. The members attested to Wiechert's reputation as a scientist and were confi- dent that he could successfully preserve the leadership position of the Potsdam-based institute. The majority of the commission signed the nomination justification (ABBAW 9). In dissent was Albrecht Penck (1858-1945) (ABBAW 10), who 4 days later submitted a counterproposal in support of geodesist Ernst Kohlschütter (1871-1942). Penck's arguments included the opinion that while he was still alive, Helmert had come out in favour of Kohlschütter. And he began his case by looking at the relationship between geodesy and geophysics: "His (Helmert's) greatest achievement was to bring the new geodesy into closer touch with geophysics. ... the boundaries between geodesy and geophysics are not blurred. For him (Helmert) this always remained a mere auxiliary science, and his research focused unwaveringly on those problems that have for centuries been assigned to the realm of geodesy." (ABBAW 11).

In the end it was Wiechert who was asked whether he would be interested in the position, but he immediately declined. In May 1918 the ministry ordered the commission to consider professors Runge (Göttingen) and Finsterwalder (Munich) (ABBAW 12). Believing Runge to be too old, the commission moved in 1918 to propose Sebastian Finsterwalder (1862-1951) (ABBAW 13 and 14). But this appointment also failed to materialise.

It would take 5 years before the directorship position could be refilled. A decree of 20 March 1922 appointed Professor Kohlschütter to the post of director of the Geodetic Institute (ABBAW 15). Kohlschütter made every effort to carry Helmert's work forward. At Kohlschütter's request, the advisory council for geodesy agreed in 1924 to name the institute's observation tower in honour of Friedrich Robert Helmert.

In the years that followed, the Geodetic Institute Potsdam did not develop in the manner seen during Helmert's times. The ban imposed on Germany by the Treaty of Versailles at the end of World War I from collaborating in international scientific associations meant that the RGIP could no longer serve as the Central Bureau of the Internationale Erdmessung. Moreover, the institute's long-standing funding and leadership problems hindered the realisation of many development plans (Buschmann, 1993b).

The institute's annual report for 1925-1926, submitted 1 year late, harvested critical commentary from academy leaders due to the small number of works published by the institute, its concentration on small-scale projects and its handling of instruments (ABBAW 16). In response, Kohlschütter explained and analysed the situation and the reasons behind the poor state of his institution. A large portion of this report was dedicated to justifying the low number of vertical deflection and gravity measurements that had been carried out. He placed the blame on a lack of funding and uncoordinated operations, but also on the slow pace of observations and the improper processing of data. In the section of the report describing the state of the facilities and instruments, Kohlschütter begins by stating that the "institute was starkly neglected 


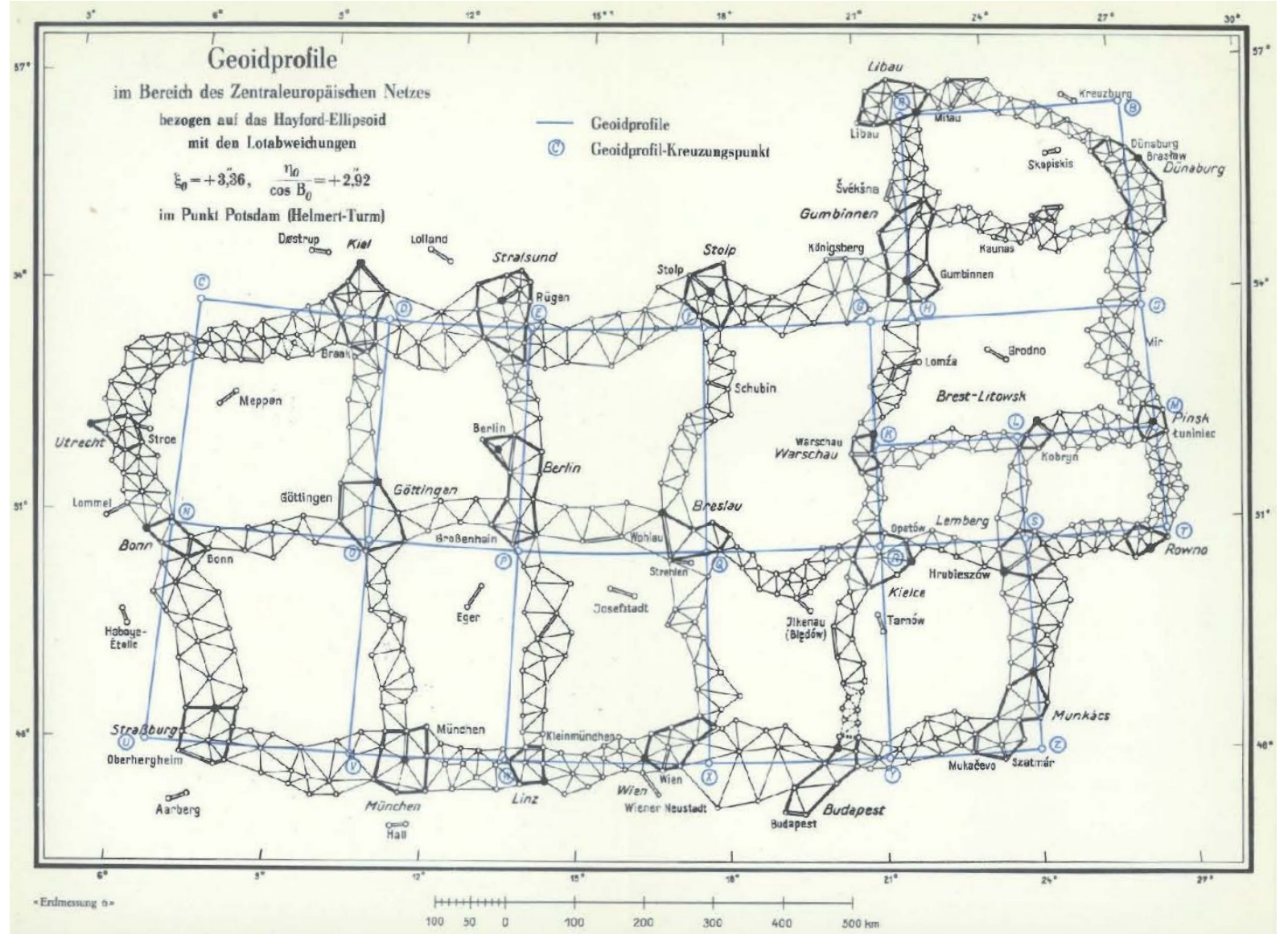

Figure 7. Configuration of the Central European Network, geoid profiles (Wolf, 1949).

due to the tribulations of the war and its aftermath". He continues, "Poorly constructed, the Helmert Tower had suffered such exceptional damage that the building authority, with the approval of my provisional predecessor, wanted to let it go completely to ruin". (ABBAW 17). One general problem experienced by the institute was the high fluctuation of scientific staff and the fact that the younger scientists were not yet able to complete projects of sufficient scale to warrant publication. The energies of the experienced staff were needed to train junior scientists in the tasks of the institute. On the whole, however, the report did not reveal how the institute could ever return to its former grandeur.

\section{The path to the present}

The conceptual seeds sown by Helmert for the discipline of geodesy had by this time taken such strong root, both in Germany and abroad, that no general relapse of the geodetic sciences was likely to occur, despite the institutional weakness of the Geodetic Institute in Potsdam. Prime credit for this consolidation goes to both the Soviet and American geodetic communities, including the work of Krasovsky, Molodenskii and the Moscow State University of Geodesy and Cartog- raphy (MIIGAiK), and that of Hayford, Bowie and the US Coast and Geodetic Survey.

After World War II the Helmert school of geodesy was carried forward in European geodetic surveying, though it was now split along east-west lines. The concepts of European Arc Measurement and the Internationale Erdmessung lived on in the work of Helmut Wolf (1910-1994) and Hellmut Schmid (1914-1998) and were brought to a certain level of scientific culmination.

Shortly after the war ended, the US Army Map Service brought the materials that had been stored by the Reichsamt für Landesaufnahme (Imperial Surveying Office), the former Prussia National Survey, in a mine in Friedrichroda, Thuringia, to the city of Bamberg in Bavaria. Wolf was in 1947 tasked with the scientific development of the Zentraleuropäisches Netz (Central European Network), or ZEN (Fig. 7), which was to serve as a preliminary study for a panEuropean network. The main elements of the ZEN are as follows: free unconstrained adjustment of the skeleton triangulation network, placement of connecting chains between the nodal points, determination of a geoid, and an adjustment of the deflection of the vertical for positioning and orientation of the network on the Hayford ellipsoid. The Helmert 
Tower in Potsdam was selected as the datum point. There was no objective reason for this selection, particularly since the Helmert Tower was not a first-order station and only be interpolated through auxiliary networks. It was far more the symbolic nature of the Helmert Tower that influenced the decision, given that the network adjustment was done based on Helmertian methods. We can say that the ZEN was an excellent example of triangulation adjustment as conceived by Helmert and Bruns by applying deflections of the vertical and geoid determinations (Wolf, 1949).

In a series of steps, the US Coast and Geodetic Survey extended the ZEN with the addition of the so-called European networks. From documents at the archives of the Federal Agency for Cartography and Geodesy, it is shown that by the early 1960s, a pan-European network stretching from Norway's north cape to the Caucasus and from Portugal's west cape to the Urals was referenced to the Helmert Tower datum.

The primary thrust of Bruns's work of 1878 was the determination of the figure of the Earth using five classes of measurements: astronomic positionings, triangulation, trigonometric and geometric levelling, and gravity measurements. At the time, purely practical reasons made it impossible to realise his idea of spanning a polyhedron around the globe. This was acknowledged and accepted by all of his contemporaries. It was not until the satellite age that the first global geodetic reference network could be established in the 1960s and 1970s with the PAGEOS worldwide network, which was based on a proposal by Hellmut Schmid, albeit with purely geometric measurements. Similar in design to the ZEN, the eastern European Uniform Astronomical Geodetic Network (UAGN) was referenced to the datum point at Pulkovo and adjusted on the Krasovsky ellipsoid. In overlapping regions, the network configurations of the European networks and the UAGN were identical.

The UAGN formed the geodetic foundation for the Warsaw Pact until its dissolution, while the ZEN and the European networks, which were based on the "European Datum" reference system, served as the geodetic foundation for NATO in Europe until the 1990s. Starting in 1967, an overarching satellite network for the UAGN was created with what became known as a "cosmic triangle" (Pulkovo-PotsdamSofia). The links were established through stellar triangulation using observations on the Helmert Tower, electronic ranging and additional astronomical measurements (Fig. 8). In this way, the Helmert Tower became a link between the geodetic foundations of the rival military blocs that faced off in Europe until 1989.

But the primary function of the Helmert Tower after the World War II was as an observation station for satellite triangulations and satellite laser ranging. It performed these tasks for projects of the International Association of Geodesy and other collaborations until 1992. The Helmert Tower had thus served for over 100 years as an observation station. Moreover, many vertical deflection and geoid height calcu-

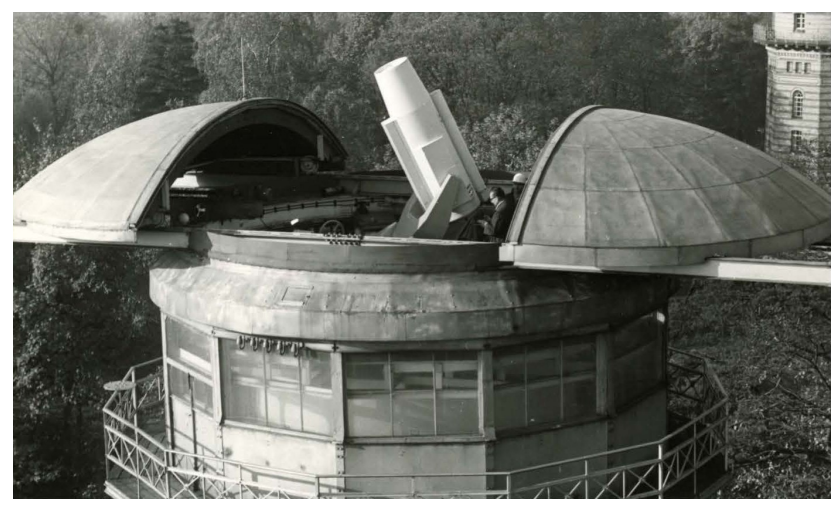

Figure 8. Helmert Tower, SBG photographic satellite camera, 1967 (photo: Zentralinstitut für Physik der Erde, ZIPE).

lations continued to be referenced to this point, allowing for the comparison of various theoretical approaches in physical geodesy. The measurements made on the Helmert Tower constituted an important contribution by the East German Academy of Sciences to east-west cooperation. The Helmert Tower has long stood as a symbol of cooperation in the Earth sciences, even during the years of political confrontation that characterised the 20th century.

\section{Epilogue}

Helmert realised how important the determination of the Earth's gravity field was for the science of geodesy and for the other Earth sciences as well. The experiments and projects he oversaw demonstrated the feasibility of his approaches. Helmert wanted to organisationally anchor gravity measurements into the work of the Internationale Erdmessung. He did not blur the boundary between geodesy and geophysics, but he did manage to shift it in favour of geodesy. What was important in the end was Helmert's contribution to creating a common theoretical framework for both disciplines.

The coalescence of many favourable factors fostered Helmert's work and lifetime achievements. Helmert had a talent for numbers, for geometry and for technology (Berroth, 1953) and thus a distinct understanding of mathematical and physical relationships. His upbringing had instilled in him strict habits of punctuality and order. The talents he possessed were recognised early on and were promoted by his teachers, motivating his work and helping him to garner authority while still young. He worked within a circle of brilliant scientists under solid organisational and financial conditions. His personality allowed him to collaborate effectively with other scientists at the institute and in the academy, as well as with the ministry and within the Internationale Erdmessung. Helmert motivated and encouraged his employees, and, with his wife's support and backing, pursued his own activities with both intellect and passion. 
Some people today believe that satellite-based geodesy has made the determination of Earth's gravity field unnecessary and irrelevant - that we can now reduce geodetic work to geometry and hence to the realm of mathematical theory. This is a fatal misconception, for in reality the opposite is true. Bruns and Helmert realised this fact over 100 years ago, and in this respect nothing has changed. Since satellite gravity missions began, the determination of the Earth's gravitational field has freed itself from being just a reduction function for geometric measurements. Such missions now allow this branch of geodesy to make an independent contribution to identifying changes of the body of the Earth.

In the years ahead, the integration of geometry and gravity of the Earth will be one of the greatest challenges facing geodesists looking to offer a sound contribution to determining changes at the Earth's surface and its interior. Geodesy has always been a part of developments in physics in terms of both theory and instrumentation. Conversely, geodesy represents an important field of application for physicists. To ensure this does not change, the international community must continuously work to keep the links between the geodisciplines and basic research strong and active. This in turn can only be achieved if science education can keep pace with scientific and technical advances. It seems worth considering to link geodesy and geophysics in education and in scientific projects even more.

The history of international geodesy also illustrates the importance of continuity in scientific institutions. After the World War II, the science centre on Potsdam's Telegraphenberg hosted the Central Institute for Physics of the Earth. Since 1992 today's Helmholtz Centre - German Research Centre for Geosciences (GFZ) has been integrated into the Albert Einstein Science Park. Together with the other geoscience disciplines, geodesy had and has found a permanent home on the Telegraphenberg.

Helmert's greatest service to his field was to construct a single edifice that could house all aspects of geodesy, allowing it to take its rightful place among the Earth sciences as a discipline rooted in mathematics and physics.

Data availability. No data sets were used in this article.

Competing interests. The authors declare that they have no conflict of interest.

Special issue statement. This article is part of the special issue "History of geophysical institutes and observatories". It does not belong to a conference.

Acknowledgements. Research support for this article was provided by the employees of the archives and history departments at the RWTH Aachen University, the Berlin-Brandenburg Academy of Sciences, the Saxon State Archives, the Main State Archive in Dresden and the Observatory in Hamburg-Bergedorf. Their assistance is deeply appreciated. The authors further wish to express their special gratitude to Harald Schuh, director of Department 1 Geodesy of the Helmholtz Centre Potsdam - German Research Centre for Geosciences, for his suggestions and ideas during the drafting of this work and Prof. Wolfgang Torge for his helpful comments and notes. We thank Wolfgang Dick and one anonymous referee for reviewing and constructively commenting on this article. Special thanks also go to Ronald Dunham for his translation of the article and for rendering many historical quotations into English.

Edited by: Kristian Schlegel

Reviewed by: Wolfgang Dick and one anonymous referee

\section{References}

ABBAW 1: Berlin-Brandenburger Akademie der Wissenschaften, Archiv, Historische Abteilung 1812-1945, Arbeitsstelle Venusdurchgänge, Nr. 12, Personalia, Blatt 11, 1872-1874.

ABBAW 2: Berlin-Brandenburger Akademie der Wissenschaften, Archiv, Historische Abteilung 1812-1945, Sternwarte Babelsberg, Nr. 206, Internationale Organisation der Gradmessungsarbeiten, 17, 1884-1888.

ABBAW 3: Berlin-Brandenburger Akademie der Wissenschaften, Archiv, Historische Abteilung 1812-1945, Sternwarte Babelsberg, Nr. 206, Internationale Organisation der Gradmessungsarbeiten, 32, 1884-1888.

ABBAW 4: Berlin-Brandenburger Akademie der Wissenschaften, Archiv Registrade: PAW (1812-1945) II-III-30, Blätter 57, 61 und 62, 1892.

ABBAW 5: Berlin-Brandenburger Akademie der Wissenschaften, Archiv Registrade: PAW (1812-1945) II-III-32, Blätter 141 bis 144 und 158 bis $160,1900$.

ABBAW 6: Berlin-Brandenburger Akademie der Wissenschaften, Archiv Registrade: PAW (1812-1945) II-III-36, Blatt 258, 1915.

ABBAW 7: Berlin-Brandenburger Akademie der Wissenschaften, Archiv Registrade: PAW (1812-1945) II-III-37, Blatt 16, 1917.

ABBAW 8: Berlin-Brandenburger Akademie der Wissenschaften, Archiv Registrade: PAW (1812-1945) II-XIV-14, Blatt 33, 1917.

ABBAW 9: Berlin-Brandenburger Akademie der Wissenschaften, Archiv Registrade: PAW (1812-1945) II-XIV-14, Blatt 35, 1917.

ABBAW 10: Berlin-Brandenburger Akademie der Wissenschaften, Archiv Registrade: PAW (1812-1945) II-XIV-14, Blatt 37f, 1917.

ABBAW 11: Berlin-Brandenburger Akademie der Wissenschaften, Archiv Registrade: PAW (1812-1945) II-XIV-14, Blatt 39ff, 1917.

ABBAW 12: Berlin-Brandenburger Akademie der Wissenschaften, Archiv Registrade: PAW (1812-1945) II-XIV-14, Blatt 53, 1918.

ABBAW 13: Berlin-Brandenburger Akademie der Wissenschaften, Archiv Registrade: PAW (1812-1945) II-XIV-14, Blatt 57ff, 1918.

ABBAW 14: Berlin-Brandenburger Akademie der Wissenschaften, Archiv Registrade: PAW (1812-1945) II-XIV-14, Blatt 60 u. 61ff, 1918.

ABBAW 15: Berlin-Brandenburger Akademie der Wissenschaften, Archiv Registrade: PAW (1812-1945) II-XIV-14, Blatt 78, 1922. 
ABBAW 16: Berlin-Brandenburger Akademie der Wissenschaften, Archiv Registrade: PAW (1812-1945) II-XIV-14, Blatt 93 und 103, 1927.

ABBAW 17: Berlin-Brandenburger Akademie der Wissenschaften, Archiv Registrade: PAW (1812-1945) II-XIV-14, Blatt 104, 1927.

Akademie-Vorträge von Friedrich Robert Helmert: Mit einer Einführung von Ernst Buschmann und einem Beitrag von Martina und Günter Harnisch, Verlag des Instituts für Angewandte Geodäsie, Frankfurt am Main, 1993.

Baeyer, J. J.: Über die Grösse und Figur der Erde - Eine Denkschrift zur Begründung einer mittel-europäischen Gradmessung, Georg Reimer Verlag, Berlin, 1861.

Baeyer, J. J.: Das Messen auf der Sphäroidischen Erdoberfläche. Erläuterungen meines Entwurfs zu einer mitteleuropäischen Gradmessung, Georg Reimer Verlag, Berlin, 1862.

Baeyer, J. J.: Mein Entwurf zur Anfertigung einer guten Karte von den östlichen Provinzen des Preussischen Staates: Ein Beitrag zur Entwicklung der Messkunde in Preussen. Georg Reimer Verlag, Berlin, 1868.

Berroth, A.: Beitrag zur Biographie und Genealogie von Friedrich Robert Helmert, ZfV, Heft 7, 210-215, 1953.

Bruns, H.: Die Figur der Erde - Ein Beitrag zur Europäischen Gradmessung, Verlag P. Stankiewicz, Berlin, 1878.

Buschmann, E. and Kautzleben, H.: Erdmessung - 125 Jahre erstes internationales geodätisches Programm, Vermessungstechnik 35, Heft 4, 110-115, Berlin, 1987.

Buschmann, E.: F. R. Helmerts Bewerbung bei J. J. Baeyer, AVN 100, Heft 10, 385-390, 1993a.

Buschmann, E.: Ein Jahrhundert Geodäsie in Potsdam, AVN 100, Heft 7, 247-265, 1993b.

Buschmann, E.: Zur Einführung, in Akademie-Vorträge von Friedrich Robert Helmert, 11-17, Verlag des Instituts für Angewandte Geodäsie, Frankfurt am Main, 1993c.

Buschmann, E. (Ed.): Aus Leben und Werk von Johann Jacob Baeyer. Nachrichten aus dem Karten- und Vermessungswesen, Frankfurt/M., Reihe I, Nr. 112, 1994a.

Buschmann, E. (Ed.): Briefwechsel zwischen Johann Jacob Baeyer und Wilhelm Foerster (1867-1868), in: Buschmann, 1994a, 145159, 1994b.

Buschmann, E.: Einst auf dem Potsdamer Telegrafenberg, Vermessung Brandenburg, 2, 2-17, 1996.

Dick, W. R.: Die Vorgeschichte von Johann Jacob Baeyers 'Entwurf zu einer Mitteleuropäischen Gradmessung', in: Buschmann, E., 105-144, 1994a.

Dick, W. R.: Zur Vorgeschichte der Mitteleuropäischen Gradmessung, in: Beiträge zum J. J. Baeyer-Symposium 1994, DGK, Reihe E, Heft 25, Frankfurt/M, 15-27, 1996.

Elstner, Cl., Harnisch, M., and Harnisch, G.: Gravimetrische Arbeiten im Geodätischen Institut und im Zentralinstitut der Erde 1870-1991, in: Zur Geschichte der Geophysik in Deutschland, Jubiläumsschrift zur 75-jährigen Wiederkehr der Gründung der Deutschen Geophysikalischen Gesellschaft, Hamburg, 182-186, 1997.

Fischer, A. and Helmert, F. R.: Zenitdistanzen zur Bestimmung der Höhenlage der Nordsee-Inseln Helgoland, Neuwerk und Wangeroog sowie des Leuchtturmes auf Roter Sand über den Festlandspunkten Cuxhaven und Schilling. Veröff. Kgl. Preuß. Geod. Inst., Verlag P. Stankiewicz, Berlin, 1895.
Galle, A., Schnauder, M., and Helmert, F. R.: Die Polhöhe von Potsdam, I. Heft. Veröff. Kgl. Preuß. Geod. Inst., Berlin, 1898.

Gast, P. (Ed.): Die Technische Hochschule zu Aachen 1870 bis 1920, Eine Gedenkschrift, Aachen, 1921.

Harnisch, M. and Harnisch, G.: Helmerts Arbeiten zur physikalischen Geodäsie, in: Akademie-Vorträge von Friedrich Robert Helmert, 37-77, Verlag des Instituts für Angewandte Geodäsie, Frankfurt am Main, 1993.

Helmert, F. R.: Studien über rationelle Vermessungen im Gebiet der höheren Geodäsie, Inaugural-Dissertation, Teubner, Leipzig, 1868.

Helmert, F. R.: Die Ausgleichsrechnung nach der Methode der kleinsten Quadrate mit Anwendungen auf die Geodäsie und die Theorie der Meßinstrumente, Leipzig, 1872a.

Helmert, F. R.: Die Übergangscurven für Eisenbahn-Geleise mit Rechnungs-Beispielen und Tafeln für den praktischen Gebrauch, Aachen, 1872b.

Helmert, F. R.: Der Stern-Haufen im Sternbild des Sobieskischen Schildes. Mit 2 Karten, Publikation der Hamburger Sternwarte Nr. 1, Hamburg, 1874.

Helmert, F. R.: Die mathematischen und physikalischen Theorieen der höheren Geodäsie. I. Teil: Die mathematischen Theorieen, Leipzig, 1880.

Helmert, F. R.: Die mathematischen und physikalischen Theorieen der höheren Geodäsie. II. Teil: Die physikalischen Theorieen: Mit Untersuchungen über die mathematische Erdgestalt auf Grund der Beobachtungen, Leipzig, 1884.

Helmert, F. R. (Ed.): Verhandlungen des Wissenschaftlichen Beiraths des Königlichen Geodätischen Instituts zu Berlin im Jahre 1886, Stankiewicz' Buchdruckerei Berlin, 1886.

Helmert, F. R.: Beiträge zur Theorie des Reversionspendels. Veröff. $\mathrm{Kgl}$. Preuß. Geod. Inst. und Centralbureaus der Internationalen Erdmessung, Potsdam, 1898a.

Helmert, F. R. and Albrecht, Th.: Der internationale Polhöhendienst, Astron. Nachr., 148, 49-56, 1898b.

Helmert, F. R.: Geodätischen Institut Potsdam [Jahresbericht 1898]. Viertelj. Schrift Astron. Ges., 34, 161-167, 1899.

Helmert, F. R.: Die Internationale Erdmessung in den ersten fünfzig Jahren ihres Bestehens, in: Int. Monatsschrift f. Wissenschaft, Kunst und Technik, 7, 1-27, 1913.

Hirsch, A. (Ed.): Verhandlungen der achten Allgemeinen Konferenz der Internationalen Erdmessung und deren Permanenten Commission, Verlag Reimer, Berlin, 1887.

Höpfner, J.: Absolute Bestimmung der Schwere mit Reversionspendeln in Potsdam. Deutsche Gesellschaft für Chronometrie, Jahresschrift, Bd. 51, 101-114, 2012.

Höpfner, J.: Bibliographie Friedrich Robert Helmert (1843-1917), available at: http://gfzpublic.gfz-potsdam. de/pubman/item/escidoc:117035/component/escidoc: 117034/JHHelmertBibliographie.pdf, Potsdam, 2013a.

Höpfner, J.: Rückblick auf ausgeführte Arbeiten und wissenschaftliche Leistungen des Geodätischen Instituts Potsdam, available at: http://gfzpublic.gfz-potsdam. de/pubman/item/escidoc:292657:2/component/escidoc: 292656/JH_RueckblickGIP_2.pdf, 2013b.

HStA Dresden 1: Sächsisches Staatsarchiv. Hauptstaatsarchiv Dresden, 10857 Kommission für die europäische Gradmessung in Sachsen, Nr. 19, 1865. 
HStA Dresden 2: Sächsisches Staatsarchiv. Hauptstaatsarchiv Dresden: 10857 Kommission für die europäische Gradmessung in Sachsen, Nr. 22, 1865.

Hülsse, J. A. (Ed.): Programm zu den am 18., 19. und 20. März 1861 mit den Schülern der Königlichen polytechnischen Schule und der Königlichen Baugewerkenschule zu Dresden zu haltenden Prüfungen, Dresden, 1861.

Kühnen, F. and Furtwängler, Ph.: Bestimmung der absoluten Größe der Schwerkraft zu Potsdam mit Reversionspendeln, Veröff. Kgl. Preuß. Geod. Inst., Neue Folge Nr. 27, Berlin, 1906.

Nagel, A. (Ed.): Astronomisch-geodätische Arbeiten für die Europäische Gradmessung im Königreiche Sachsen, 1. Abtheilung. Die Grossenhainer Grundlinie, Bearbeitet von C. Bruhns und A. Nagel, Druck und Verlag von P. Stankiewicz' Buchdruckerei, Berlin, 1882.

Nagel, A. (Ed.): Astronomisch-geodätische Arbeiten für die Europäische Gradmessung im Königreiche Sachsen, II. Abtheilung. Das Trigonometrische Netz I. Ordnung, Bearbeitet von A. Nagel, Druck und Verlag von P. Stankiewicz' Buchdruckerei, Berlin, 1890.

Peschel, H.: Gedenkrede zu Helmerts 50. Todestag am 15. Juni 1967 in Freiberg, Vermessungstechnik 15, Heft 9, 334-340, Berlin, 1967.

Rummel, R.: Fünfzig Jahre Sputnik und fünfzig Jahre Vermessung des Gravitationsfelds der Erde mit Satelliten, in: Sitzungsberichte der Leibniz-Sozietät der Wissenschaften zu Berlin, 96, 55-62, 2008.
RWTH: Rheinisch-Westfälische Technische Hochschule (RTWH) Aachen, Historisches Institut, Abteilung Hochschularchiv, Vorlesungsverzeichnisse Helmert, Fotokopie, 2003.

Schorr, R.: Die Hamburger Sternwarte. Hamburg in naturwissenschaftlicher und medizinischer Beziehung. Den Teilnehmern der 73. Versammlung Deutscher Naturforscher und Aerzte als Festgabe gewidmet, 1901.

Schüler, R., Harnisch, G., Fischer, H., and Frey. R.: Absolute Schwerebestimmungen mit Reversionspendeln 1968-1969, Veröff. Zentralinst. f. Physik der Erde, Nr. 10, Potsdam, 1971.

Torge, W.: Geschichte der Geodäsie in Deutschland, De Gruyter, Berlin-New York, 2007.

Torge, W.: From a regional project to an International Organisation: The "Baeyer-Helmert-Era" of the International Association of Geodesy 1862-1916, in: IAG 150 Years, IAG Symposia 143, edited by: Rizos, C. and Willis, P., 3-18, Springer, 2016.

UA Leipzig: Universitätsarchiv Leipzig, UAL Phil. Fakultät. Promotion 1102, 7 Blatt, 1867, 1868.

Völter, U.: Geschichte und Bedeutung der Internationalen Erdmessung, DGK Reihe C, Heft Nr. 63, München, 1963.

Wolf, H.: Beiträge zur Lotabweichungsausgleichung und Geoidbestimmung. Zweiter Teil, Tafel 12, in: Veröffentlichungen des Instituts für Erdmessung, Band 6, Bamberger Verlagshaus Meisenbach \& Co, 1949.

Wolf, H.: Friedrich Robert Helmert - sein Leben und Wirken, ZfV 118, Heft 12, 582-590, 1993. 